\title{
Perilaku Ibu Nifas Dalam Meningkatkan Produksi ASI
}

\section{Postpartum Mother's Behavior in Increasing ASI Production}

\author{
Nova Yulita1, Sellia Juwita, Ade Febriani \\ Program Studi S1 Kebidanan FKIK Universitas Abdurrab \\ 1Email: nova.yulita@univrab.ac.id
}

\begin{abstract}
ABSTRAK
Pemberian ASI ekslusif di Indonesia masih rendah. Pencapaian ASI ekslusif di Indonesia hanya 74,5\%. Cakupan bayi mendapat ASI ekslusif tahun 2018 yaitu sebesar 68,74\%. Alasan utama anak 0-23 bulan belum/tidak pernah disusui adalah karena ASI tidak keluar (65,7\%). Berbagai upaya dapat dilakukan untuk meningkatkan produksi. Tujuan untuk mengetahui perilaku ibu nifas dalam meningkatkan produksi ASI. Penelitian ini menggunakan metode campuran dengan explanatory design yang dilakukan pada bulan November 2019. Responden pada penelitian ini adalah ibu nifas di Kota Pekanbaru yang ditemui dengan cara door to door, dengan jumlah sebanyak 30 orang. Hasil penelitian ini menunjukkan perilaku ibu yang bervariasi dalam upaya peningkatan produksi ASI. Teknik menyusui yang benar sebagian telah dilakukan oleh ibu. Hanya sebagian kecil ibu yang melakukan perawatan payudara dan mengkonsumsi pelancar ASI.
\end{abstract}

Kata kunci: Perilaku, Produksi ASI, Nifas.

\begin{abstract}
Exclusive breastfeeding in Indonesia is still low. Achievement of exclusive breastfeeding in Indonesia is only $74.5 \%$. Coverage of infants gets exclusive breastfeeding in 2018 which is $68.74 \%$. The main reason that children 0-23 months have never / never been breastfed is because breast milk does not come out (65.7\%). Various efforts can be made to increase production. The aim was to determine the behavior of postpartum mothers in increasing milk production. This research was a field survei was conducted in November 2019. Respondents in this survei were postpartum mothers in Pekanbaru City who were met by door to door. The number of respondents in this survei was 30 people. The results of this survei showed that varied maternal behavior in an effort to increase milk production. Some of the correct breastfeeding techniques have been used by mothers. Only a small proportion of mothers who do breast care and consume breast milk
\end{abstract}

Keywords: Behavior, ASI Production, Puerperium.

\section{PENDAHULUAN}

ASI merupakan makanan terbaik

untuk bayi. Program pemberian ASI merupakan program prioritas, karena memberi dampak yang luas status gizi dan kesehatan balita. Kementerian Kesehatan menargetkan peningkatan target pemberian ASI ekslusif hingga 80\%. Namun pemberian ASI ekslusif di
Indonesia masih rendah. Pencapaian ASI ekslusif di Indonesia hanya 74,5\% (Balitbangkes, 2019). Berdasarkan data profil kesehatan Indonesia, cakupan bayi mendapat ASI ekslusif tahun 2018 yaitu sebesar 68,74\%. Propinsi Riau belum mencapai target renstra. Propinsi Riau hanya mencapai $35,01 \%$ dan merupakan 
terendah kedua setelah Gorontalo (Kemenkes, 2019)

Hasil Riskesdas 2018 mengungkap bahwa alasan utama anak 023 bulan belum/tidak pernah disusui adalah karena ASI tidak keluar $(65,7 \%)$. Sehingga $33,3 \%$ bayi yang berumur $0-5$ bulan telah diberikan makanan prelakteal dengan jenis makanan terbanyak adalah susu formula $(84,5 \%)$. Berbagai upaya dilakukan untuk meningkatkan produksi ASI seperti melakukan pijat oksitosin. Berdasarkan hasil penelitian Wulandari et.al 2018 mengatakan bahwa terdapat perbedaan rerata berulang yang signifikan antara produksi ASI setelah perlakuan pijat oksitosin pertama, kedua, dan ketiga. Frekuensi pijat oksitosin berbanding searah dengan peningkatan produksi ASI. Semakin sering dilakukan pijat oksitosin maka produksi ASI cenderung lebih banyak. Namun pijat oksitosin ini memerlukan orang lain untuk melakukannya. Ibu menyusui tidak bisa melakukannya secara mandiri.

$$
\text { Pranaja (2013) menyimpulkan }
$$
determinan produksi ASI adalah paritas, proses persalinan, penggunaan alat kontrasepsi, pemberian makanan pralakteral, perawatan payudara, frekuensi menyusui, dan gizi ibu. Pemenuhan kebutuhan gizi ibu menyusui sangat membantu meningkatkan kuantitas dan kualitas ASI. Selain itu berbagai produk makanan/minuman dan suplemen diformulasikan sebagai pelancar ASI (ASI Booster).

Penelitian ini bertujuan untuk mengetahui perilaku ibu nifas dalam meningkatkan produksi ASI.

\section{METODE PENELITIAN}

Penelitian ini menggunakan metode campuran (mixed method) dengan desain explanatory. Pengumpulan data dilakukan pada bulan November 2019. Responden pada penelitian ini adalah ibu nifas di Kota Pekanbaru yang ditemui dengan cara door to door. Jumlah responden ini adalah sebanyak 30 orang. Data yang digunakan adalah data primer yang diperoleh dengan memberikan kuesioner. Kuesioner berisi 10 pertanyaan tertutup tentang upaya peningkatan produksi ASI. Selanjutnya data diolah dengan analisa univariat yang menghasilkan distribusi frekuensi. 


\section{HASIL DAN PEMBAHSAN}

Tabel 1. Karakteristik responden

\begin{tabular}{llcc}
\hline \multicolumn{1}{c}{ Variabel } & \multicolumn{1}{c}{ Kategori } & Frekuensi & Persentase (\%) \\
\hline Usia Ibu & 20-35 tahun & 25 & 83,3 \\
\hline & $>35$ tahun & 5 & 16,7 \\
\hline & Jumlah & $\mathbf{3 0}$ & $\mathbf{1 0 0}$ \\
\hline Paritas & Primipara & 10 & 33,3 \\
\hline & Multipara & 20 & 66,7 \\
\hline & Grande multipara & 0 & 0 \\
\hline & Jumlah & $\mathbf{3 0}$ & $\mathbf{1 0 0}$ \\
\hline Pendidikan & Pendidikan dasar & 0 & 0 \\
\hline & Pendidikan menengah & 18 & 60 \\
\hline & Perguruan tinggi & 12 & 40 \\
\hline Status pekerjaan & Jumlah & $\mathbf{3 0}$ & $\mathbf{1 0 0}$ \\
\hline & Pekerja & 7 & 23,3 \\
\hline & Ibu rumah tangga & 23 & 76,7 \\
\hline
\end{tabular}

Karateristik usia responden paling banyak berkisar antara 20-35 tahun yaitu sebanyak 83,3\%. Sebagian besar responden $(66,7 \%)$ merupakan ibu multipara atau yang telah melahirkan lebih dari satu kali. Pendidikan terakhir yang ditempuh responden sebagian besar (60\%) adalah pendidikan menengah, dan status pekerjaan terbanyak $(76,7 \%)$ adalah sebagai ibu rumah tangga.

Hasil penelitian Rahmawati (2017) tentang faktor yang mempengaruhi Produksi ASI pada ibu bekerja. Produksi ASI merupakan volume ASI perah yang diukur selama 7 hari dengan menggunakan gelas ukur. Pemerahan menggunakan pompa ASI pada kedua payudara sebelum ibu menyusui bayinya atau 2-3 jam setelah penyusuan. Hasil analisis menunjukkan tidak ada hubungan faktor usia ibu, usia bayi, pekerjaan, pendidikan dan dukungan suami/keluarga dengan produksi ASI. Ada hubungan signifikan kuat dan berlawanan arah antara lama kerja dengan produksi ASI, ada hubungan signifikan kuat dan searah antara penambahan susu formula dan frekuensi memerah dan antara frekuensi menyusui dengan produksi ASI terdapat hubungan signifikan sedang dan searah. Namun analisis dengan uji regresi linier semua faktor tersebut menunjukkan adanya hubungan dengan produksi ASI. 
Tabel 2. Perilaku responden dalam meningkatkan produksi ASI

\begin{tabular}{|c|c|c|c|c|c|c|c|c|}
\hline \multirow{3}{*}{ PERILAKU } & \multicolumn{6}{|c|}{ FREKUENSI } & & \\
\hline & \multicolumn{2}{|c|}{ SELALU } & \multicolumn{2}{|c|}{$\begin{array}{l}\text { KADANG- } \\
\text { KADANG }\end{array}$} & \multicolumn{2}{|c|}{$\begin{array}{c}\text { TIDAK } \\
\text { PERNAH }\end{array}$} & \multicolumn{2}{|c|}{ TOTAL } \\
\hline & $\mathbf{N}$ & $\%$ & $\mathbf{N}$ & $\%$ & $\mathbf{N}$ & $\%$ & Jumlah & $\%$ \\
\hline $\begin{array}{l}\text { Ibu menyusui bayi sesering } \\
\text { mungkin (minimal } 8 \text { kali dalam } 24 \\
\text { jam) }\end{array}$ & 5 & 16.7 & 18 & 60.0 & 7 & 23.3 & 30 & 100.0 \\
\hline $\begin{array}{l}\text { lbu menyusui bayi dengan satu } \\
\text { payudara hingga payudara terasa } \\
\text { kosong }\end{array}$ & 13 & 43.3 & 17 & 56.7 & 0 & 0.0 & 30 & 100.0 \\
\hline $\begin{array}{l}\text { Ibu tetap menyusui bayi } 2-3 \text { jam } \\
\text { sekali walaupun bayi tertidur. }\end{array}$ & 5 & 16.7 & 10 & 33.3 & 15 & 50.0 & 30 & 100.0 \\
\hline $\begin{array}{l}\text { ASI diberikan dengan } \\
\text { menggunakan dot }\end{array}$ & 0 & 0.0 & 7 & 23.3 & 23 & 76.7 & 30 & 100.0 \\
\hline Ibu merasa kelelahan dan cemas & 0 & 0.0 & 30 & 100.0 & 0 & 0.0 & 30 & 100.0 \\
\hline $\begin{array}{l}\text { Ibu mengkonsumsi makanan } \\
\text { dengan menu seimbang }\end{array}$ & 10 & 33.3 & 15 & 50.0 & 5 & 16.7 & 30 & 100.0 \\
\hline $\begin{array}{l}\text { Ibu melakukan } \\
\text { perawatan/pemijatan khusus pada } \\
\text { payudara }\end{array}$ & 0 & 0.0 & 6 & 20.0 & 24 & 80.0 & 30 & 100.0 \\
\hline $\begin{array}{l}\text { Ibu minum air putih minimal } 12 \\
\text { gelas }\end{array}$ & 5 & 16.7 & 16 & 53.3 & 9 & 30.0 & 30 & 100.0 \\
\hline $\begin{array}{l}\text { Ibu mengkonsumsi suplemen } \\
\text { pelancar ASI }\end{array}$ & 10 & 33.3 & 7 & 23.3 & 13 & 43.3 & 30 & 100.0 \\
\hline $\begin{array}{l}\text { Ibu mengkonsumsi sayuran atau } \\
\text { jamu khusus untuk pelancar ASI }\end{array}$ & 9 & 30.0 & 21 & 70.0 & 0 & 0.0 & 30 & 100.0 \\
\hline
\end{tabular}

Perilaku responden dalam meningkatkan produksi ASI berada pada tingkatan sedang. Tidak banyak responden yang secara terus menerus melakukan upaya peningkatan ASI. Pada poin 1 tentang frekuensi menyusui bayi hanya $16,7 \%$ responden yang selalu menyusui lebih dari 8 kali/24jam. Sebagian besar menjawab dengan frekuensi kadang-kadang. Dari wawancara responden 2 mengatakan "ASI diberikan kapan bayi mau misalnya kalo nangis, kadang ya bayi tidurnya agak lama ya gak dibangunkan".

Lama menyusui hanya $43,3 \%$ yang selalu menyusui sampai payudara terasa kosong. Responden lainnya tidak selalu menyusui sampai payudara kosong (kadang-kadang). Menurut responden 1, lama menyusui sesuai keinginan bayi saja, terkadang sampai bayi tertidur atau melepaskan putting susu payudara masih terasa keras. Saat bayi tertidur sebagian 
besar responden $(50 \%)$ tidak penelitian Arfiah menunjukkan sebagian membangunkan bayi untuk menyusui.

Perilaku responden dalam penggunaan dot sudah baik, karena sebagian besar tidak menggunakan dot dalam pemberian ASI (76,7\%). Responden yang menggunakan dot beralasan karena bekerja dan bayi dijaga oleh orang lain. Hasil penelitian Tauriska (2015) 94,1\% responden menunjukkan isapan bayi yang benar, dan hampir seluruhnya mempunyai produksi ASI yang cukup. Semakin sering bayi menghisap dengan benar, ASI semakin sering di produksi. Demonstrasi cara menyusui yang benar meningkatkan keyakinan seseorang dalam kemampuannya untuk berhasil menyusui bayinya (breastfeeding self efficacy).

Rasa cemas dapat menimbulkan berbagai masalah seperti mempengaruhi produksi ASI. Dalam penelitian ini seluruh responden (100\%) merasakan kelelahan dan cemas. Responden 3 mengatakan "sering lelah ketika menyusui di bulan-bulan pertama terutama saat bangun malam, kalo siang jika tidak ada suami susah juga karena tidak ada yang bantuin". Responden 5 juga merasa cemas dengan kemampuan memberikan ASI secara ekslusif, serta khawatir jika nanti kembali bekerja. Hasil besar responden mengalami kecemasan sedang dan $62 \%$ mengalami pengeluaran ASI yang tidak lancar, dengan nilai $\mathrm{p}=0,000$ berarti terdapat hubungan tingkat kecemasan dengan pengeluaran ASI (Arfiah, 2018).

Perilaku yang selalu mengkonsumsi menu seimbang hanya dilakukan oleh sebagian responden $(33,3 \%)$. Sebagian besar responden (50\%) mengkonsumsi menu seimbang dengan frekuensi kadang-kadang. Berdasarkan pedoman gizi seimbang diketahui konsumsi masyarakat belum sesuai dengan pesan gizi seimbang, hal ini berkaitan dengan cakupan ASI ekslusif yang masih rendah. Konsumsi pangan ibu menyusui harus beragam dan bergizi seimbang agar memenuhi kebutuhan zat gizi dan produksi ASI. Protein dibutuhkan untuk sintesis hormone prolactin dan oksitosin. Zat gizi mikro yang dibutuhkan selama menyusui adlah zat besi, asam folat, vitamin A, B1, B2, B3, B6, C, D, iodium, zink, selenium. Menurunnya konsentrasi zat gizi tersebut menyebabkan turunnya kualitas ASI (Sugihantono, 2014).

Sanima (2017) melakukan penelitian tentang cara ibu untuk meningkatkan produksi ASI yaitu dengan 
memperhatikan pola makan seperti makan tepat waktu dan mengkonsumsi makanan secukupnya berupa sayuran, daging, kacang-kacangan, buah-buahan, susu dan air putih. Jenis makanan yang dapat meningkatkan produksi ASI adalah kacang-kacangan yang berwarna gelap seperti kacang merah dan kenari. Buahbuahan yang mengandung vitamin $\mathrm{C}$ dan anti oksidan seperti jeruk, blueberry,apel, papaya,stroberi, alpukat. Makanan pokok berupa beras putih atau merah, gandum, jagung dan ubi. Sayuran berwarna hijau seperti bayam, selada, brokoli, daun katuk, labu siam dan ketimun. Ikan seperti tuna, salmon, lele, daging ayam, telur, daging sapi, tahu, tempe. Susu sapi dan susu kedelai (Mufdillah, 2017).

Perawatan khusus seperti pemijatan pada payudara sangat penting dilakukan. Berdasarkan hasil penelitian sebagian besar $(80 \%)$ responden tidak pernah melakukan pemijatan pada payudara. Menurut pernyataan responden mereka tidak mengetahui cara pemijatan yang dilakukan pada payudara. Penelitian Katuuk (2018) terdapat hubungan yang signifikan antara pengetahuan perawatan payudara dengan kelancaran produksi ASI pada ibu post partum. Sebagian besar responden yang memiliki pengetahuan baik dan produksi ASI lancar dikarenakan ibu post partum telah penyuluhan dari petugas kesehatan tentang perawatan payudara pada masa hamil sampai menyusui (Katuuk, 2018).

Jenis pemijatan payudara sangat bervariasi. Penelitian Usman (2019) melakukan kombinasi metode pijat Woolwich dengan massage rolling (punggung). Kombinasi metode ini dilakukan pada saat kunjungan rumah sehingga dapat meningkatkan partisipasi keluarga dalam upaya peningkatan ASI. Metode pijat oksitosin juga dapat dilakukan untuk mempelancar ASI. Hasil penelitian Albertina (2015) terdapat hubungan yang signifikan antara pijat oksitosin dengan kelancaran ASI pada ibu post seksio sesarea hari ke 2-3.

Air merupakan sumber cairan yang paling baik. Penambahan jumlah air yang harus dikonsumsi ibu menyusui adalah $850-1000 \mathrm{ml}$ per hari atau setara dengan 12-13 gelas. Jumlah tersebut dapat memproduksi ASI sekitar 600-850 ml perhari(Sugihantono, 2014). berdasarkan hasil penelitian ini hanya $16,7 \%$ responden yang memenuhi kebutuhan air 12 gelas perhari $(3000 \mathrm{ml})$. Pantangan bagi ibu menyusui adalah makanan dan minuman yang mengandung alkohol minuman bersoda atau yang mengandung soda lainnya serta 
minuman yang mengandung caffein dan teh. (Mufdillah, 2017). Berdasarkan hasil penelitian ini, sebagian besar $(43,3 \%)$ responden tidak pernah mengkonsumsi suplemen pelancar ASI. Namun mayoritas renponden mengkonsumsi pelancar ASI melalui sayuran dan jamu. Berdasarkan hasil wawancara dengan responden mengatakan "kebiasaan dalam keluarga dan tetangga hanya makan sayur dan buah untuk meningkatkan ASI, tidak ada yang menggunakan obatobatan". Hasil penelitian Johan et al (2019) menyimpulkan bahwa daun kelor memiliki potensi dalam meningkatkan produksi ASI. Peningkatan produksi ASI diukur melalui berat badan bayi, frekuensi $\mathrm{BAK}$, frekuensi $\mathrm{BAB}$, dan frekuensi menyusui.

\section{SIMPULAN DAN SARAN}

Perilaku ibu dalam meningkatkan produksi ASI belum maksimal. Sebagian besar perilaku yang mendukung peningkatkan produksi ASI dilakukan tidak secara terus menerus (kadangkadang). Hasil penelitian ini menunjukkan perilaku ibu yang bervariasi dalam upaya peningkatan produksi ASI. Teknik menyusui yang benar sebagian telah dilakukan oleh ibu. Hanya sebagian kecil ibu yang melakukan perawatan payudara $(20 \%)$ dan mengkonsumsi pelancar ASI secara terus menerus $(33,3 \%)$.

Kepada bidan agar dapat memberikan penyuluhan tentang cara pemberian ASI yang meningkatkan produksi meliputi frekuensi menyusui on demand, lama menyusui, posisi menyusui.

\section{DAFTAR PUSTAKA}

Albertina, M et.al 2015. Hubungan pijat oksitosin dengan kelancaran produksi ASI pada ibu post partum seksio sesarea pada hari ke2-3. Jurnal Husada Mahakam volume III No 9 Mei 2015. http://husadamahakam.poltekkeskaltim.ac.id/ojs/index.php/Home/ $\underline{\operatorname{article} / \text { view/22/29 }}$

Arfiah, 2018, Pengaruh pemenuhan nutrisi dan tingkat kecemasan terhadap pengeluaran ASI pada ibu post partum primipara, Jurnal Kebidanan AKPB Volume 8 Nomor 2. P-issn 2252-8121 e-issn 2620-4894

https://media.neliti.com/media/pu blications/278230-pengaruhpemenuhan-nutrisi-dan-tingkat-k$\underline{\text { 2dc1868d.pdf }}$

Balitbangkes, 2019. Laporan Nasional RISKESDAS 2018. ISBN 978602-373-116-3 Kemenkes RI. http://labmandat.litbang.depkes.g o.id/images/download/laporan/R KD/2018/Laporan_Nasional_RK D2018_FINAL.pdf

Johan, Herni. Et al 2019. Potensi minuman daun kelor terhadap 
peningkata produksi Air Susu Ibu (ASI) pada ibu post partum. Jurnal Sebatik Vol 23 No 1 Juni 2019 eISSN 2621-069X. https://jurnal.wicida.ac.id/index.p hp/sebatik/article/view/468/174

Katuuk, M \& Rina Kundre, 2018, Hubungan pengetahuan perawatan payudara dengan kelancaran produksi ASI pada ibu post partum di ruangan Dahlia RSUD Liun Kendaghe Tahuna Kabupaten Kepulauan Sangihe, e-journal Keperawatan(e-Kp) volume 6 no 1 Februari 2018, https://ejournal.unsrat.ac.id/index .php/jkp/article/view/25180/2487 $\underline{7}$

Kemenkes, 2019. Profil Kesehatan Indonesia 2018. ISBN 978-602656-446-4. Jakarta. https://pusdatin.kemkes.go.id/res ources/download/pusdatin/profilkesehatan-indonesia/Data-danInformasi_Profil-KesehatanIndonesia-2017.pdf

Pranaja, R dan Novita Rudiyanti, 2013. Determinan Produksi ASI pada Ibu Menyusui. Jurnal Keperawatan Vol. IX No. 2 Tahun 2013 ISSN 1907-0357

Rahmawati, Anita dan Bisepta Prayogi (2017). Analisis Faktor yang Mempengaruhi Produksi ASI pada Ibu Menyusui yang Bekerja. Jurnal Ners dan Kebidanan Vol. 4 No 2 tahun 2017. DOI: 10.26699/jnk.v4i2.ART.P134140.

https://pdfs.semanticscholar.org/7 11a/9ef4c6dc55890263ec94e13fa 9b4b5b88cd1.pdf? ga $=2.246385$ 932.946494728.15776737841170290166.1577478735
Sanima et al (2017). Hubungan pola makan dengan produksi ASI pada ibu menyusui di Posyandu Mawar Kelurahan Tlogomas Kecamatan Lowokwaru Kota Malang. Nursing News, Vol 2, No 3 tahun 2013.

https://publikasi.unitri.ac.id/index .php/fikes/article/view/576/461

Sihombing, Setia (2018). Hubungan Pekerjaan dan Pendidikan Ibu dengan Pemberian ASI Ekslusif di Wilayah Kerja Puskesmas Hinai Kiri Tahun 2017. Jurnal Bidan "Midwifery Journal" Vol. 5 No. 01 2018. eissn 2477-345X. https://media.neliti.com/media/pu blications/234018-hubunganpekerjaan-dan-pendidikan-ibude-e6545e26.pdf

Sugihantono, Anung. 2014. Pedoman Gizi Seimbang. Bina Gizi dan KIA. Kementerian Kesehatan RI. Jakarta.

https://drive.google.com/file/d/0 ByRIDMiFQLUAWDZzcDlycH FqR00/view

Tauriska, Tri Aprillia, faridah umamah, 20. Hubungan antara isapan bayi dengan produksi ASI pada ibu menyusui di Rumah Sakit Islam Jemursari Surabaya. Jurnal Ilmiah Kesehatan, Vol 8, No 1 2015. Hal 15-21

http://journal.unusa.ac.id/index.p $\underline{\mathrm{hp} / \mathrm{jh} / \text { article/view/130/118 }}$

Usman, H, 2019, Kombinasi metode pijat woolwich dan massage rolling (punggung) mempengaruhi kecukupan ASI pada ibu post partum di wilayah kerja puskesmas Mapane Kabupaten Poso, Jurnal Bidan Cerdas (JBC) 
volume 2 no 1 april 2019, ISSN 2654-9352

http://jurnal.poltekkespalu.ac.id/i ndex.php/JBC/article/view/148/1 $\underline{15}$

Wulandari, P., Kustriyani, M., Aini, K (2018). Peningkatan Produksi
ASI Ibu Post Partum melalui Tindakan Pijat Oksitosin. Jurnal Ilmiah Keperawatan Indonesia. Vol.2 (1): 33-49 http://jurnal.umt.ac.id/index.php/j ik/article/view/1001/7 